\title{
Geographical Satellite and Survey Data for Prediction of Dengue Cases in Sukoharjo, Indonesia
}

\author{
Dyah Kusumawati'), Adi Prayitno²), Ruben Dharmawan²) \\ 1)Academy of Health Analyst 17 Agustus 1945, Semarang, Indonesia \\ ${ }^{2)}$ Masters Program in Public Health, Sebelas Maret University, Surakarta
}

\begin{abstract}
Background: Dengue fever is a disease based on environment and still a health problem. Problems related to the dengue fever vector distribution factor in terms of the spread of vector space with the use of geographic data and survey data in order to predict the incidence of dengue in the region.

Subjects and Method: This study used analytic observational with cross sectional approach using modeling Geographical Information Systems (GIS). The sampling technique in this research is saturated sampling of secondary data Sukoharjo District Health Profile in 2011-2014, population data and data Geographic, then all the data were analyzed using multiple linear regression.

Results: There is a positive relationship between the area per $\mathrm{Km} 2$ with the number of new cases of dengue fever, although the relationship was not statistically significant. $(\mathrm{B}<0.01 ; 95 \% \mathrm{CI}=-0.01$ to $0.02 ; \mathrm{p}=0.310$ ). There is a positive relationship between population density per soul/ $\mathrm{Km}^{2}$ with number of new cases of dengue fever, a significant relationship between population density with DHF cases $(\mathrm{B}<0.01 ; 95 \% \mathrm{CI}=0.01$ to $0.01 ; \mathrm{p}=0.013)$. There is a negative relationship between topography per masl by the number of new cases of dengue fever, although the relationship was not statistically significant $(\mathrm{B}<0.01 ; 95 \% \mathrm{CI}=-0.02$ to $0.01 ; \mathrm{p}=0.335)$. There is a positive correlation between rainfall per $\mathrm{mm} /$ year with the number of new cases of dengue fever, although the relationship was not statistically significant $(\mathrm{B}<0.01 ; 95 \% \mathrm{CI}=0.01$ to $0.01 ; \mathrm{p}=0.101)$. There is a positive relationship between river flow per ha by the number of new cases of dengue fever, although the relationship was not statistically significant $(\mathrm{B}=0.02 ; 95 \% \mathrm{CI}=-0.01$ to $0.03 ; \mathrm{p}=$ 0.318). There is a negative correlation between\% Non Flick figure by the number of new cases of dengue fever, although the relationship was not statistically significant. $(\mathrm{B}<0.01 ; 95 \% \mathrm{CI}=-0.02$ to $0.01 ; p=0.764)$.

Conclusion: The increase in land area, population density, rainfall, river flow is predicted to affect the increase in dengue cases, whereas the increase ABJ predicted topography and affecting the decline of dengue cases in the district of Sukoharjo in 2011-2014.
\end{abstract}

Keywords: geographical data and survey data, prediction of dengue cases

\section{Correspondence:}

Dyah Kusumawati. Academy of Health Analyst 17 Agustus 1945, Semarang, Indonesia. Email: dyahkusumawatiwinarno@yahoo.co.id. Mobile: 085876563978

\section{BACKGROUND}

Indonesia is an archipelagic state that consists of 17,508 island, located between 2 continents and 2 oceans, having tropical climate which is heterogenic and rich of flora and fauna including various kinds of disease with mosquito as the infecting agent such as dengue fever. Diseases with mosquito as infecting agent including dengue fever are based on environment and very complex. It can not be solved only with Health Science. The entire regions of Indonesia are at risk for Dengue fever since the virus that cause and mosquito the infecting agent (aedes aegypty) are widely spread whether it is in houses as well as public places, except for places with its altitude more than 1,00o meter above sea level 
Journal of Epidemiology and Public Health (2016), 1(1): 11-17

https://doi.org/10.26911/jepublichealth.2016.01.01.02

(Kemenkes RI, 2011). Since several years ago Indonesia has endured epidemiology and demography transition, environmental degradation, urbanization, industrial sector development, health technology and science development, information flow improvement, globalization, and transportation development which are very rapid. The changes either direct or indirect brings positive and negative effect toward environmental or ecosystem quality that will influence toward incident rate and disease transmission which is transmitted through infecting agent such as dengue fever (Sukowati, 2010). Dengue fever still becomes health problem in Indonesia and endemic in some regencies/ cities. Almost every rainy season extraordinary events occurs in some regions. The number of patients is likely to be increasing, the spreading is getting extensive, and it attacks not only children but also those who are older (Kemenkes RI, 2012).

In 2004 there were 334 regencies/cities that were infected by dengue fever, in 2006 it increased into 340, in 2007 it made another increase into 357 regencies/ cities. in 2008 it reduced to 346 regencies/cities. In 2007 a total cases were 156,767 (IR 71.18) with 1570 deaths (CFR= $1.00 \%)$. In 2008 a total cases reduced to 98.869 people $\quad(\mathrm{IR}=43.62) \quad$ (Sukowati, 2010). By the end of 2010 Indonesia was quite busy with dengue fever outbreak that expanded and infected children and adult (Puspitasari R, Susanto I, 2011). Based on the record of Health Office of Sukoharjo Regency, in 2007 there were 184 dengue fever cases, in 2008 there were 367 cases, in 2009 there were 440 cases and 434 cases in 2010. The data from Sukoharjo Regency Health Office dengue fuver virus infected Sukoharjo, Central Java. During January March 2015, 10 people were hospitalized. In Sukoharjo, 7 out of 12 sub districts were categorized as dengue fever endemic status. The seven sub districts were Kartasura, Sukoharjo, Grogol, Baki, Weru, Nguter, dan Mojolaban.

The Government of Sukoharjo Regency stipulated the status of dengue alert. According to Head of Disease Control Section of Disease Eradication and Environmental Health Division of Sukoharjo Regency, Bambang Sudiyono, stated that the national measuring of alert status of dengue spread is determined whenever there are 100 patients with $2 \%$ of them die. The government of Sukoharjo Regency launched half an hour of mosquito nest eradication movement (PSN) at homes. The activity that was conducted simultaneously in the entire regency was carried out to answer the circular letter of Sukoharjo Regent No. 400/ 582/ 20 February 2015 about the eradication of mosquito nest. At least once in a week spare 30 minutes to carry out mosquito nest eradication at home and its surrounding. And immediately take any member of family whose body temperature was high for more than 2 days to healthcare facility as the prevention and countermeasure effort of dengue fever.

Dengue fever is one of contagious diseases that is caused by dengue virus which is transmitted through A. aegypti and A. albopictus mosquitos' bite. It is not yet fully overcome since it is difficult to cut off the transmission chain and there is no vaccine found yet for the prevention (Pangemanan et al., 2009). Dengue fever is an environmental based disease and still becomes health problem. The dependency level of dengue fever in a region is estimated to be affected by dengue fever in other regions nearby. Dengue fever spread in terms of space and time through mosquito's bite from one sufferer to other people from one place to another (Yatim, 2007). 
Seeing the high number of dengue fever cases in Sukoharjo, therefore it needed to conduct study related to the diseases. It is an epidemic disease and it may be transmitted through the space component. Dengue fever spreading is varied from one place to another, therefore the space component extremely takes part and should be noticed (Tri Yunis et al., 2010).

Based on the background the writer was interested to study about dengue fever related to the vector spreading factor which was reviewed from vector spreading space by utilizing geographical data and survey data. The utilization of geographical data was expected to be faster, cheaper, and covered wider area compared to conduct field survey. The purpose of the study was:

1. Determining the association among territorial extent, population density, topography, rainfall, stream, mosquito larva free rate toward dengue disease incidence in Sukoharjo Regency region

2. Determining how big the influence of territorial extent, population density, topography, rainfall, stream, mosquito larva free rate toward dengue disease incidence in Sukoharjo Regency region

\section{SUBJECTS AND METHOD}

The study used observational analysis with cross sectional approach using Geographic
Information System (GIS) modeling by utilizing geographical data from satellite image which was combined with survey data. Sampling technique used in the study was saturated sampling from secondary data of Sukoharjo Regency Health Profile 2011-2014, demographic data and geographic data, afterward the entire data obtained was analyzed by using multiple linear regression test

\section{RESULTS}

The average region of sub-district in SukoharjoRegency is $388,908 \mathrm{~km}^{2}$ with the smallest region is $19.20 \mathrm{~km}^{2}$ and the largest region is $62.20 \mathrm{~km}^{2}$. The average population density in Sukoharjo Regency is 23,148 people $/ \mathrm{km}^{2}$. The average topography in Sukoharjo Regency is 108.33 masl with the lowest region is $89.00 \mathrm{al}$ and the highest is 125.00 masl. The average rainfall is 161.65 $\mathrm{mm} /$ year the lowest rainfall is $0.00 \mathrm{~mm} /$ year and the highest rainfall is $322.00 \mathrm{~mm} /$ year.

The average stream is $9.51 \mathrm{Ha}$ with the smallest stream is $1.00 \mathrm{Ha}$ and the biggest is $23.50 \mathrm{Ha}$. The average mosquito larva free rate is $84.77 \%$ with the lowest is $58.46 \%$ and the highest mosquito larva free rate is $96.25 \%$. The average case of dengue fever is 13.27 cases per year with the least is o case and the most is 58 cases.

Table 1. Multiple linear regression analysis on territorial extent, population density, topography, rainfall, stream, mosquito larva-free rate factors with dengue fever cases

\begin{tabular}{lcccc}
\hline \multirow{2}{*}{ Variables } & \multirow{2}{*}{$\mathbf{B}$} & \multicolumn{2}{c}{$\mathbf{9 5 \%}$ CI } & \multirow{2}{*}{ p } \\
\cline { 3 - 4 } & & Lower Limit & Upper Limit & \\
\hline Territorial extent $\left(\mathrm{Km}^{2}\right)$ & $<0.01$ & -0.01 & 0.02 & 0.310 \\
Population density $\left(\right.$ people $\left./ \mathrm{Km}^{2}\right)$ & $<0.01$ & $<0.01$ & 0.01 & 0.013 \\
Topography (masl) & -0.01 & -0.02 & 0.01 & 0.335 \\
Rainfall (mm/year) & $<0.01$ & $<0.01$ & 0.01 & 0.101 \\
Stream (Ha) & 0.02 & -0.01 & 0.03 & 0.138 \\
Mosquito Larva-Free Rate (\%) & $<-0.01$ & -0.02 & 0.01 & 0.764 \\
Constanta & 1.03 & -1.45 & 3.52 & 0.407 \\
Adjusted $\mathrm{R}^{2}=17.9 \%$ & & & & \\
$\mathrm{p}=0.001$ & & & & \\
\hline
\end{tabular}


Journal of Epidemiology and Public Health (2016), 1(1): 11-17

https://doi.org/10.26911/jepublichealth.2016.01.01.02

The largest region is Polokarto sub district which is $62.80 \mathrm{~km}^{2}(13.29 \%)$, whereas the smallest region is Kartosuro sub-district which is $19.23 \mathrm{~km}^{2}(4.12 \%)$. The region with the highest population density is Kartosuro sub district which is in average 4900.54 people $/ \mathrm{km}^{2}(19.59 \%)$, whereas the region with the lowest population density is Bulu sub-district which is in average 1175.60 people $/ \mathrm{km}^{2}$ (4.89\%). Region with the highest topography is Polokarto sub-district which is located on 125 masl (9.73\%), whereas region with the lowest topography is Grogol sub-district which is 89 masl (6.70\%). Region with the highest average rainfall per year is Bendosari sub-district with $204.75 \mathrm{~mm}$ (10.67\%), whereas region with the lowest average rainfall is Bulu subdistrict with $99.5 \mathrm{~mm}$ (4.98\%).

The biggest stream is located in Polokarto sub-district which is $15.75 \mathrm{Ha}$ (13.79\%), whereas the smallest stream is located in Bulu sub-district which is $1.00 \mathrm{Ha}$ (0.09\%). The annual average mosquito larva -free rate is $79.41 \%-85.55 \%$, whereas the percentage is $8.33 \%-9.21 \%$. The average cases of dengue fever per year is 13 cases, the least case occurred in 2102 with a total is 45 cases (in average 3.75 cases), whereas the most case occurred in 2013 with a total is 265 cases (in average 21.08 cases). During 2011-2014 a cycle of dengue fever incidence occurred, the number of cases declined between 2011-2012 however dengue cases increased quite high in 2013 (83\%), in 2014 the number of cases decreased again although it was only for about $17 \%$. The highest case in 2011 happened in Kartosuro and Grogol sub district with a total 21 cases (19.63\%), in 2012 the highest cases happened in Grogol and Sukoharjo sub district as many as 9 kasus (20.0\%).

In 2013 the highest cases happened in Grogol sub-district with a total 58 cases (21.89\%), whereas in 2014 the highest cases happened in Kartosuro sub district with 34 cases (15.45\%).

Table 1 shows the multiple linear regression analysis on the association of Geographic and Demographic Factors with Dengue Cases. It shows positive association between territorial extent per $\mathrm{km}^{2}$ with number of dengue fever new cases, although the association was statistically insignificant. Each $1 \mathrm{~km}^{2}$ of territorial extension would also increase the incidence. In other word every square kilometer of territorial extension would increase the additional case by 0.01 dengue fever cases $\quad(b<0.01 ; 95 \%$ $\mathrm{CI}=-0.01$ to $0.02 ; \mathrm{p}=0.310$ ). There was a positive association between population density per person/Km2 with number of new cases of dengue fever and statistically significant. Every increase of 1 person/Km2 would increase the number of dengue fever new cases by $<0.01$ of dengue fever case (b<0.01; 95\% CI <0.01 to 0.01; $\mathrm{p}=0.013$ ). There was a negative association between topography per masl with number of dengue fever new cases, although the association was statistically insignificant. Every 1 masl topography increase would reduce the number of new dengue fever case. In other words every 1 masl topography increase would reduce by 0.01 of dengue fever case $(\mathrm{b}<0.01 ; 95 \% \mathrm{CI}=-0.02$ to $0.01 ; \mathrm{p}=0.335)$. There was a positive association between rainfall per $\mathrm{mm} /$ year with the number of new dengue fever cases, although it was statistically insignificant. Every $1 \mathrm{~mm} /$ year rainfall increase would increase number of new dengue fever cases by $0.002(b<0.01$; $95 \% \mathrm{CI}<0.01$ to $0.01 ; \mathrm{p}=0.101$ ).

There was a positive association between per Ha stream with the number of dengue fever new cases, although it was statistically insignificant. Every 1 Ha stream increase would increase the number of new dengue fever cases by 0.02 case $(b=0.02$; $95 \% \mathrm{CI}=-0.01$ to $0.03 ; \mathrm{p}=0.318$ ). 
There was a negative association between percentage of Mosquito Larva-Free Rate with the number of new dengue fever cases, although it was statistically insignificant. Every 1\% Mosquito Larva-Free Rate reduction, would increase the umber of new dengue fever cases. In other words every $1 \%$ Larva-Free Rate increase would reduce by 0.01 of dengue fever cases $(b<0.01 ; 95 \% \mathrm{CI}=$ -0.02 to $0.01 ; \mathrm{p}=0.764$ ).

Territorial extent, population density, topography, rainfall, stream and Larva-Free Rate variables or factors as regression equation were able to elaborate the dengue fever case incidence by $\mathbf{1 7 . 9 \%}$, meanwhile the remaining $82.1 \%$ was explained by other variables/factors which was not included in linear regression model or was not investigated.

\section{DISCUSSION}

Territorial extent positively affected toward the incidence of dengue fever cases, the territorial extension would increase the incidence of dengue fever cases. Along with the extension of territory subsequently the vector which causes dengue fever will have much bigger space to breed and transmit dengue virus to other human.

Population density positively affected toward the incidence of dengue fever cases, high population density potentially generated high cases of dengue fever. It supports the opinion and study result of Rahayu (2010), that overcrowded housing/high population density facilitates mosquitoes to transmit dengue disease/ virus, considering mosquito's habit which is doing multi bites and also its flying distance is only $50-100$ meter.

Topography negatively affected toward the incidence of dengue cases. It means that the higher the topography was (altitude above sea level), it would reduce the incidence of dengue fever cases. It can be explained that the mosquito as infection agent of dengue fever exists in almost the entire corner of Indonesia but not in places that are beyond 1000 meter above sea level (Kementerian Kesehatan Republik Indonesia, 2011).

Topography in Sukoharjo is between 95-125 masl. Therefore potentially become breeding area of $A$. aegypti mosquito, the vector of dengue fever. The higher altitude of one area topography will affect the growth of mosquito as dengue fever vector. High topography affects toward humidity, temperature, air pressure which can affect also toward mosquito flying range. Some factor which were not studied namely temperature, humidity, and air pressure. Temperature is one of the environmental factors that affect the growth of A. aegypti mosquito larva (Sugito, 1989 dalam Ririh dan Anny, 2005).

Commonly mosquito will lay its eggs in temperature about $20-30^{\circ} \mathrm{C}$ (Iskandar et al, 1985 dalam Ririh dan Anny, 2005). The average optimum temperature for mosquito's growth is $25^{\circ}-27^{\circ} \mathrm{C}$ and will completely stop whenever the temperature is less than $10^{\circ} \mathrm{C}$ or more than $40^{\circ} \mathrm{C}$. Besides room temperature, humidity is also one of environmental that affect the development of Aedes aegypti larva. Humidity that ranges between $81.5-89.5 \%$ is an optimal humidity for the development process of embryo and survival of mosquitos' embryo (Mardihusodo, 1988 dalam Ririh dan Anny, 2005).

Rainfall positively affected toward the incidence of dengue fever cases. The higher rainfall was, it would increase dengue fever cases. In accordance with the study by Amah Majidah Vidyah Dini, Rina Nur Fitriany, Ririn Arminsih Wulandari in 2010, that states that rainfall has direct effect toward the existence of brood place of A.aegypti. Population of $A$. aegypti depends on the brood place. Heavy rainfall and lasts for 
Journal of Epidemiology and Public Health (2016), 1(1): 11-17

https://doi.org/10.26911/jepublichealth.2016.01.01.02

quite some time may cause flood so it may eliminate the brood place of Aedes mosquitos that usually live in clean water. Consequently the number of brood place will be reduced so that mosquito population will be also reduced, however, if the rainfall is low and in long period of time, it will add place of brood and increase mosquito population. As other vector based diseases, dengue fever shows pattern that is related to climate especially rainfall since it affects the spreading of mosquito vector and it is possible transmitting virus from one person to others. (EHP, 2008).

Yanti (2004) states that numerous rainy days with high rainfall will cause flood that washes away the brood place so that the number of brood place will also decrease. Meanwhile, few rainy days with high rainfall but with long period of time will add to brood place and increase mosquito population. It is in accordance with the rainfall in Sukoharjo Regency in which the average rainfall per year was between 99.5 - 204.75 with the average rainy day was only 2 days however the time of occurrence is almost 10 months in a year.

Stream positively affected toward dengue fever incidence. It means the bigger the stream was, it would increase dengue fever cases. Stream is land area that is passed by water flow with certain volume of water. The larger the stream is, it potentially become brood place of mosquitos.

Mosquito Larva-Free Rate negatively affected toward dengue fever. It means that the lower the Mosquito Larva-Free Rate is, it would increase dengue cases. The Mosquito Larva Free Rate indicated the spreading area of mosquito larva in the investigated region. The mosquito Larva Free Rate would be considered high if there was no larva found in the surveyed area. And it was considered low if the was larva found. Mosquito Larva Free Rate became the indicator of fogging effectiveness and early prevention of denge fever. If the rate was low then the investigated region potentially became mosquito habitat as vector.

Geographic data can be ustilized to predict incidence or cases of dengue fever. Geographic data are presented in a form of map that shows the geographic condition of a region, although it is in a form of data with certain category, it can support secondary data that is presented in a form of health profile. By utilizing satellite geography data then a region may predict the incidence of dengue fever cases based on climate change or geographical condition of the area so that it may attempt the prevention effort toward the occurrence of outbreak.

\section{REFFERENCE}

Achmadi UA (2010). Manajemen Demam Berdarah Berbasis Wilayah, Buletin Jendela Epidemiologi. (2):15-20

Anonim (2010). Demam Berdarah Dengue Di Indonesia Tahun 1968-2009. Buletin Jendela Epidemiologi.(2):1-14.

Brisbois BW, Ali SH(2010). Climate Change, Vector-Borne Disease and Interdisciplinary Research: Social Science Perspectives on an Environment and Health Controversy. Ecohealth, Heidelberg: Springer.

Charter D, Agtrisari I (2004). Desain dan Aplikasi Geographics Information System. Jakarta: PT Elex Media Komputindo.

Devriany A (2012). Analisis Eko-Epidemiologi Status Endemisitas Demam Berdarah Dengue (DBD) Di Provinsi Sulawesi Selatan Tahun 2011. Jurnal Masyarakat Epidemiologi Indonesia. (1)1.

EHP (2008). Dengue Reborn Widespread Resurgence of A Resilient Vector. Environmental Health Perspectives. (9):116. 
Fitriany RN, Vidyah Dini AM, Wulandari RA (2010). Faktor Iklim Dan Angka Insiden Demam Berdarah Dengue Di Kabupaten Serang,Makara, Kesehatan, 14(1): 31-38.

Hastono SP (2007). Analisis Data Kesehatan. Depok: Fakultas Kesehatan Masyarakat Universitas Indonesia.

Kasjono HS (2011). Penyehatan Pemukiman, Gosyen Publising, Yogyakarta.

Kementerian Kesehatan Republik Indonesia. (2011). Modul Pengendalian Demam Berdarah Dengue, Direktorat Jendral Pengendalian Penyakit Dan Penyehatan Lingkungan.

Kementerian Kesehatan Republik Indonesia. (2012). Subdirektorat Pengendalian Arbovirosis-Dit PPBB-Ditjen PP dan PL.

Murti B (2013). Desain dan Ukuran Sampel untuk Penelitian Kuantitaif dan Kualitatif di Bidang Kesehatan, Yogyakarta: Gadjah Mada University Press.

Oishi K,Saito M, Mapua CA, Natividad FF (2007). Dengue Illnes: Clinical Features and Pathogenesis. Journal Infect Chemother.(13):125-133.

Pangemanan J, Nelwan J (2009). Perilaku Masyarakat Tentang Program Pemberantasan Penyakit DBD, di Kabupaten Minahasa Utara, Jurnal FKM, Universitas Sam Ratulangi Manado.

Prahasta E (2002). Konsep-konsep Dasar Sistem Informasi Geografis. Bandung: Penerbit Informatika.

Radji M (2010). Imunologi dan Serologi, Jakarta: PT. ISFI Penerbitan.

Ririh Y, Anny V (2005). Hubungan Kondisi Lingkungan, Kontainer dan Perilaku Masyarakat Dengan Keberadaan Jentik Nyamuk Aedes aegypty Di Daerah
Endemis DBD Surabaya, Jurnal Kesehatan Lingkungan (1):2.

Sitorus J (2003). Hubungan Iklim dengan Kasus Penyakit Demam Berdarah Dengue di Kotamadya Jakarta Timur tahun 1998-2002. Tesis. Fakultas Kesehatan Masyarakat, Universitas Indonesia.

Sri Rejeki (2004). Tata Laksana Demam Berdarah Dengue Di Indonesia: Depkes RI, Direktorat Pemberantasan Penyakit Menular Dan penyehatan Lingkungan.

Sukowati S (2010). Masalah Vektor Demam Berdarah Dengue (DBD) dan Pengendaliannya di Indonesia, Buletin Jendela Epidemiologi. (2): 26-30.

Tri Yunis MW, Haryanto B, Mulyono S, Adiwibowo A (2010). Faktor-faktor yang Berhubungan Dengan Kejadian Demam Berdarah dan Upaya Penanggulangannya di Kecamatan Cimanggis, Depok, Jawa Barat, Buletin Jendela Epidemiologi. (2):31-43.

WHO (1997).Dengue Haemorrhagic Fever, Diagnosis, treatment, prevention and control. 21 ${ }^{\text {st }}$ edition. Geneva.

Yanti (2004). Hubungan Faktor-Faktor Iklim dengan Kasus Demam Berdarah Dengue di Kotamadya Jakarta Timur Tahun 2000-2004. Skripsi. Fakultas Kesehatan Masyarakat, Universitas Indonesia.

Yatim F (2007). Macam-macam Penyakit Menular dan Cara Pencegahannya. Jakarta: Pustaka Obor Populer. 